\title{
„...ÚGY ÉRZEM, MINTHA KIESNÉK EBBÖL A VILÁGBÓL.” A LÉLEKTANI KRÍZIS ÁTMENETI TAPASZTALATÁNAK NARRATÍV SAJÁTOSSÁGAI
}

\section{B. ERDŌS MÁRTA}

Pécsi Tudományegyetem, Bölcsészettudományi Kar, Közösségi és Szociális Tanulmányok Tanszéke

E-mail: erdos.marta.gabriella@gmail.com

\begin{abstract}
Háttér: A lélektani krizis során a személyes identitást szervezô központi jelentések alkalmassága, stabilitása megkérdöjelezôdik. A korábbi szervezôdések felbomlása új koherencia kialakulásával jár. Az újjászervezódés folyamatainak pontosabb megértéséhez olyan elméletek lehetnek segítségünkre, mint az identitás strukturális analizise (Weinreich, 2003), a batesoni (1972) másodfokú változás gondolatköre, vagy a „második esély”, a „második születés” konstrukciói alapjául szolgáló átmeneti vítusok elmélete. A krizisállapothoz kapcsolódó autobiografikus szövegek értelmezésének fóbb kérdéseit elsôsorban a diszkurzí pszichológia (Harré, 1998; 2004, Kézdi, 2003) és Hanninen (2004) narratív cirkulációs modelljének elméleti keretei között tárgyaljuk.
\end{abstract}

Célok: A lélektani krízis állapotában keletkezố, a mélyreható változásokat megmutató, egyben érvényre juttató önreflektív szövegek, élettörténeti epizódok vizsgálata, különös tekintettel az átmenet sürgós beavatkozási pontot jelentố liminális fázisára.

Módszer: Cry for help beszélgetés kvalitatív tartalomelemzése.

Eredmények: Az eredmények rávilágítanak a narratív identitás felbomlásának és újjászervezôdésének folyamataira, a megélt (élményszintü), a belsô és az elbeszélt, a személyességen túl a kulturális konvenciókat is megjelenítô narrativa kapcsolódási pontjaira, és e folyamatok nyelvi leképezôdésére.

Konklúzió: Krizisben az élettörténeti forgatókönyv, az események elrendezése, a kulcsfontosságú jelentések gyökeres változáson mennek keresztül. A személy tudatában van létezése folytonosságának, önmagával való azonosságának, mégis gyakran újjászületésként, második esélyként tekint a sorsfordító krízisek nyomán megélt ugrásszerú változásra. A változás középsố, liminális szakasza egyes sajátosságainak ismerete - íy a paradoxonok és az ambivalencia, az elveszni látszó kontroll nyelvi jegyei, a sajátos idốviszonyok leképezése, a forgatókönyveket szervezó és magukba sưrítô konceptuális metaforák, mint pl. a zuhanás-kapaszkodás - a segítô beavatkozások során fontos tájékozódási pontokként szolgálnak a gyakorló szakember számára.

Kulcsszavak: lélektani krízis, liminalitás, másodfokú változás, jelentés 


\section{BEVEZETÉS}

A segítô szakmák emberképét a tudományos eredmények mellett az aktuális társadalmi-gazdasági tényezốk is meghatározzák: ezek függvényében alakulnak elméleteink az egészség és a betegségek természetérôl, a két állapot közötti átmenetekrôl, a betegségek várható idôtartamáról és a gyógyulás várható hozadékáról. (Foucault, 2000; Pikó, 2002). E tényezôk befolyása nyomán a krízisteória és a hozzá kapcsolódó változásorientált praxis idôrôl időre háttérbe szorul, majd újra felbukkan a segítô professziók területén.

Lindemann korábbi munkásságának eredményire építve Caplan (1964) - korának vezetô elméleteihez és fizikalizáló terminológiájához alkalmazkodva - a homeosztázis fogalmából kiindulva ír le egy, a hétköznapok rendjébe nem illeszthetô sorsfordító állapotot. A lélektani krízis teóriája, bár elismeri a megterhelố helyzetre adott személyes reakciók fontosságát, egyértelmúen hangsúlyozza a kontextuális (társadalmi, társas, szituatív) tényezôk szerepét. Így az elméletben már a kezdetektôl benne rejlik annak lehetôsége, hogy a krízisállapotra az emberi élet normális részeként tekintsünk, hangsúlyozva a viszonylag gyorsan, hetek alatt bekövetkezô pozitív változások lehetôségét. Johnson és munkatársai éppen ezért nevezik a krízist tranzitív diagnózisnak (Johnson, Pfenninger, Klion, 2000). A krízisállapot definíciójának négy alapvetô eleme: a váratlan veszély/sérülékeny állapot, a sürgetettség, a személyes értékrendben (is) megjelenô beszükülés („megoldása mindennél fontosabb”), valamint a tehetetlenség a narratíva alakulását meghatározó összetevook (Poal, 1990). A lélektani krízis megoldása - a definíció értelmében is - az identitás mélyreható változását vonja maga után, hiszen a személy számára korábban el nem érhetô megoldásokra, kapcsolati készségekre, megküzdési stratégákra kell szert tennie egy aktuálisan mindennél fontosabbnak értékelt, központi jelentôségú kérdésben. A korai rekompenzációs modell, ahol a törekvés az elôzô egyensúlyi állapot helyreállítására irányult, még akcidentális krízisek esetében sem múködne jól; a megküzdési készségek fejlődése vagy a kapcsolathálózat átalakulása, rekonstrukciója elengedhetetlen a krízisből történô felépüléshez. „A világ újrafelfedezésének kell megtörténnie, ahol a dolgok jelentése és jelentôsége változik meg, és a jövô ismeretlen dimenziói nyílnak meg” (Maruna, Wilson és Curran, 2006, 167).

\section{VÁLTOZÁSELMÉLETEK}

Milyen elméletek húzódnak meg a krízisteória hátterében, és hogyan segíti ezek megismerése a krízisnarratívák elemzését? Minden ilyen elméletben közös, hogy a káosz-rend fogalompárok mentén gondolkodik, valamint a kialakuló rendezettség eltérô fázisait, szintjeit különbözteti meg. Az átmeneti rítusok elmélete Van Gennep (1960) múvének angolra fordítását követôen Turner újraalkotó gondolatai nyomán talált utat a terápiás környezetben lezajló változások magyarázatára (Kelemen és B. Erdôs, 2004; Seltzer és Seltzer, 1988; Turner 1982, 2002). Van Gennep egy univerzális mintázatot ír le, ami a státuszok, szerepek, identitásváltozások hátterében felfedezhetô. Hagyományosan az átmeneti rítusok szerkezete a születésünkkor megélt mintázatokat követi (Grof, 1988). A beavatandó elszakad korábbi környezetétôl, státuszátától, szerepeitôl, iden- 
titásától, amelyek további fejlôdését nem teszik lehetôvé. Egy köztes térbe, a küszöb(liminális) térbe kerülve tehetetlen várakozást, majd intenzív próbatételeket él át. Ezt követốen - ha próbálkozásait hitelesítik - új státuszt nyerve, új szerepekhez jutva, új identitással lesz részese a közösség életének. A liminális térben tartósan megrekedve, a továbblépés reménye nélkül azonban kialakul a marginalizálódás. Tacey (2005) az öngyilkosságot egy „téves rítus” eredménynek tartja. Az elôzó identitás szimbolikus halála - azaz a szeparáció fázisa - az átmenetben szükségszerú. A szimbolikus minôség nyersbe fordulása az a tévút, amelyre a veszteség fájdalma és a kaotikus állapotból fakadó szorongás viheti a személyt (B. Erdôs, 2006).

Turner (1982) az átmenet közösségi vonatkozásait bontja ki. Minden társadalom, societas két összetevốje a struktúra és a communitas. Ez utóbbi a társadalmi cselekvést vezérlô, motiváló, a mindennapokban rejtetten létezô eszmények rendszere, mely a struktúrához képest szabad, egyben kaotikus, rugalmas, újjászervezhetô, a normák, értékek tudatosulását megkönnyítô ellentétes minôség, az antistruktúra. A communitas elburjánzása a káosszal, a fenntarthatatlansággal fenyeget, míg a merev strukturáltság az energiák, a motivációk, a jövôkép elvesztéséhez, a remény feladásához vezet. Míg a communitas élmény hagyományos társadalmakban a rituális, átmeneti terekhez kötôdött, a modernitás, különösen a késố modern a maga képére formálta ezeket a tereket: megjelent a kvázi-liminális, a liminoid.

Bahtyin (1982) a jelentésváltozás feltételeinek vizsgálata során szintén foglalkozott az antistruktúra kaotikus, veszélyes, ugyanakkor felszabadító tapasztalatával. Az identitás alakulásában központi szerepet játszó jelentéseket két erô, a centripetális, a jelentéseket beszúkítô, zárttá, de egyben jobban meghatározhatóvá, koherensebbé, kiszámíthatóbbá tevố mozgás, valamint a centrifugális, alternatívákat nyitó, a változatokat és változatosságot adó dinamika formálja. A személy forrásokat keresve megnyitja, vagy integritásának, koherenciájának védelmében lezárja nyelvének és gondolkodásának határait.

Bateson (1972) az élố rendszerek legfontosabb sajátosságának információfeldolgozó képességüket tekinti, ennek megfelelően vizsgálja a jelentések (konstrukciók, kategóriák) keletkezésének és változásának mikéntjét. A rendszer szintjén bekövetkezô változást, a központi konstrukciók megváltozását - ami túlmutat a rendszer egyes elemei közötti váltásokon - másodfokú változásnak nevezi. E leírásban a másodfokú változás alapvetô hasonlóságokat mutat az átmeneti rítusok eredményezte változások, identitásalakulások folyamatával: a változásnak ezt a szintjét veszélyek, rendezetlenség, ambivalencia és a megoldás felé mutató paradoxonok egyaránt jellemzik. A jelentések zártságát, a változás blokkolását egy különleges kommunikációs csapda, a kettôskötéshelyzetek (a késôbb elemzésre kerülô szövegben: „kutyaszorítók”) tudják fenntartani. A kettôs kötés lényege, hogy az eltérô színtereken, szinteken, kommunikációs csatornákon a fenyegetô utasításként megfogalmazott vagy akként értelmezhetô üzenetek feloldhatatlan ellentmondásba kerülnek egymással. Ugyanakkor az összeegyeztethetetlen utasításokat megfogalmazó tekintélyszeméllyel való kapcsolat az egyén számára létfontosságú. Ilyenkor a kényszerítô erejû paradoxon hozza létre az adott kapcsolati rendszeren belül a „sem megoldani, sem elkerülni” helyzeteket. A kettôs kötés az elvárásokat, beállítódásokat tartósan formálja, ha a tanulási folyamat lezajlott, nincs többé szükség külsố fenyegetésre a csapda múködéséhez. 
Bár a kettős kötés elmélete mint a skizofrénia létrejöttének magyarázó elveként terjedt el hazai szakmai körökben, és ebben a formájában nem is bizonyult tarthatónak, az eredeti leírásban sok olyan vonatkozásra találhatunk, amely hasznos magyarázatokat kínál témánk szempontjából. Bateson (1972) szerint a kettóskötés-helyzetek eredménye az összezavarodás, a bénultság, a passzivitás. Mindez végsố soron destruktív-öndestruktív mintázatokat hívhat elô, a helyzet megoldása helyett annak nem-reflektált visszhangja („megbolondulás”) vagy a helyzet megszüntetése helyett a cselekvés/a cselekvô kikapcsol(ód)ása, megszüntetése (szerhasználat, öngyilkosság) következhet be. A személyes és társadalmi patológiákat összekapcsoló skizmogenezis a hibás és pusztító, tévedéseken alapuló episztemiológia renddé avatása (B. Erdôs, Kelemen, 2011). Smith (2002) egy antropológiai értekézésében társadalmi oldalról a kettős kötés elmélete alapján magyarázza a magyar öngyilkossági szcéna sajátosságait.

A kettôskötés-helyzetekre ugyanakkor kínálkozik egy konstruktív alternatíva, amit Bateson (1972) transzkontextuális kreativitásnak nevezett. Ez a lépés másodfokú változást (Watzlawick, Weakland és Fish, 1990), a narratíva szintjén asszimiláció helyett akkomodációt feltételez (Neimeyer, 2006): a személy nem az ellentmondó utasítások közül próbál egyiknek vagy másiknak eleget tenni, hanem az eredeti szituációra, kontextusra reflektálva, a paradoxont akár humorral oldva, átformálja azt. A kettôskötés-helyzetek fontos szövegszintú megnyilvánulásai az üres vagy lebegó jelölôk. A konszenzuson alapuló szóhasználattól való távolság ilyenkor az értelmezést és a feloldást megnehezíti (Máthé-Tóth, 2011).

Klinikai környezetben, a terapeuta vagy tanácsadó nézőpontjából az ontológiai-ismeretelméleti kérdések gyakran reflektálatlanul maradnak, pedig a segító kapcsolatban nagy lehet a jelentôsége annak, hogy a segítô miként gondolkodik ezekrôl. Poal (1990), áttekintve az eredeti koncepció fontosabb kiegészítéseit, megállapítja, hogy a krízisteória kiforrottnak tekinthetô, de a krízisintervenció kapcsolódó gyakorlatának kidolgozása további kutatásokat igényel.

A lélektani krízis definíciója a nyelvi fordulat elôtti fizikai analógiákra támaszkodik; mégpedig a newtoni fizikáéra. Az újabb fejlemények: a káoszelmélet és a kapcsolódó nonlineáris dinamika fogalmi kapaszkodóit igénybe véve sokkal jobban leírhatóak a krízisállapot történései és a tanácsadó szerepe. A nyílt rendszerek - a komplex adaptív rendszerek, amelyek önmagukat szervezik - nonlineárisak (Bussolari és Goodell, 2009). A szerzók a tanácsadói gyakorlatról szóló kritikai írásukban arra hívják fel a figyelmet, hogy a tradicionális, racionalizmusra és lineáris logikára épülô modell és a hétköznapokban hatékony, nonlineáris logikára építô tanácsadói gyakorlat között lényegi ellentmondás feszül. Olyan modellre van szükség, amelyik képes kezelni, magyarázni a folyamatban kibontakozó, előre kiszámíthatatlan változásokat (bifurkációkat). Az emberi fejlôdés nem a homeosztázis fenntartását jelenti, hanem az állandóan változó, egyben változatos környezethez való rugalmas alkalmazkodást, lehetôséget a folytonos, de egyenetlen fejlôdés jegyében. Ha abból indulunk ki, hogy a zúrzavaros, rendezetlen állapot előfeltétele a pozitív változások bekövetkeztének, akkor a kliensnek nem lesz szüksége többé önmaga vagy mások hibáztatására, mert el tudja fogadni, hogy az aktuálisan nyomasztó állapot az élet velejárója. Nem ó maga „okozza” saját zavaros állapotát, és az akár jelentéktelennek tûnô, apró pozitív változásokra való nyitottsággal döntô pozitív eredményeket érhet el. E rendszerszemléletú megközelítés 
egyik fö üzenete a krízisteóriáéval azonos: „az érzelmi rendellenesség magyarázatát ne a személyben keressük [...] hanem a zúrzavaros környezetben és a kapcsolati rendszerekben, amelyekben a kliens éli az életét" (Bussolari és Goodell, 2009, 98). Komplex, fejlôdô rendszerek esetében az átmeneti káosz elkerülhetetlen. A terapeuta fó kérdése, hogy vajon a káosz aktuálisan produktív vagy destruktív, az átmenet zavarosságának elviselését vagy a mielôbbi rendezôdést kell-e segíteni? (Gergen és McNamee 2000; Mahoney, 2000). Mi a konstruktív terápiás változás? Miképpen és milyen mértékben képes az ember a változásra? Honnan tudhatjuk, hogy a változás sikerrel lezajlott? Egy pragmatikus felvetés szerint nem is az a kérdés, mi a valóság, hanem az, hogy milyen valóság hasznos a kliensnek? (Rober, 2002).

\section{NARRATÍV MODELLEK ÉS NARRATÍV IDENTITÁS}

Az identitásfejlődés, változás útja a szimbolikus rendszereken, így a nyelven keresztül vezet. A nyolcvanas-kilencvenes évek narratív fordulata nyomán a szelf és az identitás mint narratív konstrukció került értelmezésre (Bruner, 1990; Gergen és Gergen, 1983; Harré, 1998; László, 2005; McAdams, 2006; Weinreich, 2003; White és Epston, 1990). A figyelem e fordulattal a homo narransra irányult, aki tapasztalatainak, élményeinek jó részét narratív formában rögzíti és osztja meg (Neimeyer, 2006). Identitásunkat azok a történetek formálják, amelyeket mi mondunk el önmagunkról, amelyeket a számunkra jelentôs mások mondanak el rólunk, és amelyeket velük együtt szövünk életünk folyamán. „Amikor elmondom Neked, ki vagyok, elmondom a végzetemet. Ahhoz, hogy a végzetemen változtassak, újra meg kell határoznom önmagam, és át kell alakitanom a saját történetemet" (White, 1996, 423).

A fordulat közelebbrôl nézve az individuális-társas kontinuum mentén jól elrendezhetô egymástól eltérô elméleti és kapcsolódó módszertani megközelítéseket hozott létre. E konceptualizációkat az egyéni-társas tengelyen való elhelyezkedésükön, azaz a kognitív struktúrákra vagy a társas-társadalmi cselekvésre helyezett hangsúlyokon túl jól jellemzi az is, hogy milyen ontológiai és ismeretelméleti kiindulópontok szerint határozzák meg a narratívák szerepét az identitás és a társas valóság alakításában. A neorealista nézôpont szerint a narratíva lehet a belsố vagy társas valóságra adott pontos és érvényes, vagy éppen torz és diszfunkcionális interpretáció. A realista nézôponttól eltávolodva, a radikális konstruktivista vagy szociális konstrukcionista szerzốk pedig a közösen konstruált (co-constructed), a történetmondásban megváltozó és változékony, számos perspektívát ötvözô valóság egy kitüntetett modalitásaként tekintenek a narratívára. Smith és Sparkes (2008) elméleti áttekintésükben öt eltérô perspektívát különböztetnek meg: a pszichoszociális, az interszubjektív, a történetforrás (storied resource), a dialogikus és a performatív nézôpontokat. A pszichoszociális perspektíva az identitás alakításában meghatározónak tekinti a személy szerepét és koherenciateremtô törekvését. Az interszubjektivitást hangsúlyozó nézôpontok Mead (1973) elméletére alapoznak; ezekben az elméletekben a társas visszatükrözésnek (I-Me) - de még inkább hitelesítésnek (validation) és a szelf-reflektivitásnak, a mentalizációnak tulajdonítanak kitüntetett szerepet a narratív identitás alakulásában. A történetforrás-perspektíva szerint az individuum a kultúra hordozója, a személy identitását „kumulatív 
narratív források mátrixa” alakítja (Smith, Sparkes, 2008, 16). A narratíva ugyan személyes, de forrásai kulturálisak, publikusak.

A bahtyini elméletre és Vigotszkij (1967) felfogására visszavezethetô dialogikus és különösen a szelf és identitás értelmezhetôségét megkérdôjelezô performatív keretben a nyelv használata olyan kapcsolathálózati cselekvés, amelyben a döntôbb a társas hatás. A nyelv nem kifejezôje a gondolatnak, hanem maga a gondolat a beszéddel együtt keletkezik. Míg azonban a dialogikus elméletekben a szelf kontinuitása megmarad - bár saját kapcsolathálózata számtalan lehetséges pozíciót teremt meg a történetmondó számára, aki belsố szólamok sokaságából választva szövi meg a maga történetét -, addig ez a kontinuitás a performatív elméletek tükrében illúziónak tûnik. A beszélók azáltal, hogy elmondanak egy történetet, egy, a társas valóságot folytonosan újjáalakító aktus részeseivé válnak (Smith és Sparkes, 2008). Rober (2002) egy klinikai eset elemzésén keresztül mutatja meg, hogy a terapeuta tudása gyakran nem elôre rögzített módon múködik (prognózis), hanem menetközben, a terápiás dialógusban alakul, és csak utólag fogalmazódik meg rendezett ok-okozati viszonyok mentén.

Hanninen (2004) az interszubjektív felfogás egy változatának tekintett narratív cirkulációs modelljében (Smith és Sparkes, 2008) a jelentésstruktúrák három különbözó modalitását különbözteti meg: az elbeszélt (told), a belsô (inner) és a megélt (lived) módot. Egy nagyon hasonló, de a mikronarratívákra vonatkozó tipológia szerint külsố (megfigyelhetô események), belsố (az eseményekre adott érzések, reakciók), valamint reflektív (a történetnek tulajdonított jelentés, értelmezések) módot különböztethetünk meg (Angus, Levitt és Hardke, 1999; Neimeyer, 2006).

A belsô narratíva a személyes élmények interpretációján alapszik, és - szituatív korlátok között - cselekvéseinket vezérli. Felvetôdhet persze az imént tárgyalt elméleti kérdés, hogy létezik-e egyáltalán „belsô”, amennyiben a belsô narratíva eredetére kérdezünk rá; praktikus azonban mégis belsônek tekinteni azt, amit az egyén és környezete - mivel interiorizált tapasztalatról, azonosulásokról, értelmezésrôl, értékelésrôl van szó - belsôként ismer fel. A belsố narratíva részben elbeszélt narratívává válhat, amelyet a személy a számára elérhetô kulturális forrásokra támaszkodva tud megalkotni, és amelyre a környezet reflektál, hitelesíti vagy felülvizsgálatára készteti az egyént. A narratív cirkuláció modelljének további hangsúlyos elemei - a három narratív módon túl - így a személyes és kulturális történettár. A krízis egyben a személyes történettár egyfajta csôdje, deficitje. Az egyén ilyenkor a társas-kulturális környezet, a kulturális történettár korábban be nem épített elemeire tud támaszkodni (Neimeyer, 2006), amennyiben nyitott tud maradni a fenyegetố helyzetben is, és nem veszi kezdetét a preszuicidális szindrómára jellemzô beszúkülés (Kelly, 1955; Ringel, 1974). A folyamatban a kulturális történettár egyes alkotóelemei és szervezôdései az egyén személyes történeteivé válnak, átszínezik az élmények, a napi tapasztalatok, és eközben kialakul a személy érzelmi kötôdése ezekhez az általa érvényesnek választott történetekhez (Hammack, 2008).

Az identitás strukturális analízise (Weinreich, 2003), mint szintetizáló elmélet, abból indul ki, hogy az emberek folyamatosan értelmezik és értékelik életük eseményeit, egyszersmind azonosulnak személyekkel vagy társadalmi intézményekkel. Az elmélet kellôképpen átfogó ahhoz, hogy jól magyarázza a domináns nyugati kultúrától eltéró jelenségvilágot: más kultúrák tapasztalatait vagy a „nem normális” állapotokat. 
Az elmélet és a hozzá kapcsolódó gyakorlat szinte minden korábbi és kortárs elméletalkotó munkáját beépíti valamilyen módon. Legerôsebben Kelly (1955) személyi konstrukciók elméletére, Erikson (1968) fejlôdéslélektani koncepciójára (azonosulások, elkötelezôdések, az identitásdiffúzió fogalma, a kulturális kontextus jelentôsége), Festinger (2000) kognitív disszonancia elméletére, valamint Harré (1998) diszkurzív pszichológiájára támaszkodik. Weinreich kiemeli, hogy személyes életünkben folyamatosan zajlik az értelem keresése: kik vagyunk most, honnan jöttünk, és mit gondolunk, mit várunk, hová tartunk. Az identitás önmagunk értelmezésének sajátos, narratív minôsége; Weinreich felfogásában a saját szelfünkrôl alkotott konstrukcióink összessége, ahol a jelenlegi konstrukciók kifejezik a múlt személyes konstrukcióival mutatkozó kontinuitást, valamint alakítják a szelfre vonatkozó, jövôvel kapcsolatos saját elvárásokat. A szelf és az identitás közötti különbség lényege annak felismerése, hogy a szelf egy kapcsolati hálózatban létezik és változik (Weinreich, 2003).

Az identitás a társas világnak az egyén számára releváns entitásairól szóló diskurzusok személyes értékelésének, jelentôségének függvénye. Meghatározó, központi értékelô dimenziói a személyes történet, narratíva függvényében alakulnak - a történet egyfajta fölérendelt konstrukciónak tekinthetô. Az idôbeli kontinuitáson túl az identitás fontos jellemzője a koherencia, az egyes konstrukciók egymáshoz való illeszkedése. Az ISA keretrendszerében nagy jelentôsége van a szelf jelenlegi, korábbi és a jövôbe vetített állapotainak, a jelentôs Másoknak, a szelfrôl tett explorációknak és az ún. metaperspektívának, a jelentôs Másik perspektívájáról adott saját értelmezéseknek („X szerint én...”). A szelf tehát megjelenhet, mint

- ágens (intencionális cselekvések, interakciók, értékelés);

- reflektív szelf (minden személy sajátos és egyedi, rá jellemző tulajdonságokkal rendelkezik, amelyek változhatnak az idô folyamán, de van kontinuitásuk, és így egyedileg jellemzóek maradnak);

- nyilvános szelf, az, ahogyan a személy önmagát megmutatni törekszik. (Harré, 1998; Weinreich 2003, 2010).

A három szelf-összetevốt megfeleltethetjük Hanninen három narratív módjának: az ágentikus a megélt, a reflexív a belsố és a nyilvános szelf az elmondott történet föszereplője. Ezek egymáshoz való viszonya krízisben különösen éles kérdéssé válhat. Mivel a narratíva is, a személyiség is változik, így megeshet, hogy az „act as if”, a „mintha” kétes és képlékeny valóságából megélt belsô realitás lesz; ezen alapszik pl. Kelly rögzített szerepterápiája, ezt tükrözik a felépülô kultúra tapasztalatai, az ún. konverziós narratívák és a másodszor születés konstrukciója (Hyden, 1995; Kelemen és B. Erdōs, 2004; Maruna, Wilson és Curran, 2006). A narratíva az illeszkedés megteremtésének érdekében a személyes identitás aktuális konstrukcióiról és nem a korábban megélt és elbeszélt múltról fog szólni.

Az empirikus kutatásokban vagy a megélt narratíva, tehát a megfigyelhetô események egymásutánisága, a személyes élet narratív szervezôdése, vagy az elbeszélt narratíva a vizsgálat tárgya. Témánk szempontjából a krízisben elmondott történetek általános sajátosságain túl az egyik legizgalmasabb kérdés az lesz, hogy miképpen válik a „szubnarratívák sokaságát tartalmazó és eltérô fokban reflektált” (Hanninen, 2004) belsố narratíva elbeszélt narratívává? 


\section{A BELSŐ NARRATÍVA ÉS A MÉG KI NEM MONDOTT (NOT YET SAID)}

A terápiás kapcsolat kezdete gyakran valamilyen aktuálisan zajló krízisállapothoz vagy a korábbi megoldatlanságok nyomán jelentkezô diszfunkciókhoz kötôdik. A titkok, elhallgatások, rejtett, reflektálatlan (azaz „tudattalan”) tartalmak jelentôsége Freud óta ismert. Egy újabb felvetés szerint a terápiás folyamat lényege a még-ki-nem-mondott, a not-yet-said kimondása. Anderson és Goolishian (1988) szerint a puszta meghallgatással legfeljebb a leírás duplikációjáig juthatnánk el. A kliens igyekezetén túl a terapeuta részvétele, elismert vagy el nem ismert, az emberi kommunikáció alapvetô törvényszerûségeibôl következô aktivitása az, ami a változást előmozdítja, és aminek révén lehetôvé válik a tapasztalatok, élmények közös explorációja. A dialogikus elméleti keretben gondolkodva, a not-yet-said esetében a terapeuta közlését a korábban elnémított belsố szólamok (voices) egyike-másika fogadja, majd erre rezonálva, az alternatívák felfedezésével jön létre az újfajta cselekvéseket lehetôvé tévô új történet (Rober, 2002).

A traumatikus élményekrôl szóló narratívák három különbözô módon szervezôdhetnek: a dezorganizált narratíva esetében a traumatizáló élményre (pl. valami szélsôséges eseményre) egyszerúen nincsenek szavak; a disszociált narratívák azok a néma történetek, amelyeket nem lehet nyilvánossá tenni, a domináns narratívák pedig egy zárt világot, negatív koherenciát képviselnek a személy számára, ami szerint élnie kellene, de ami szerint nem tud élni. Egy éppen zajló krízisben kimondatlanságaink, a „prenarratíva”, a „belsố narratíva” hátterében kétféle, egymással összefüggó magyarázatot kereshetünk: az egyik a batesoni kettôs kötés, ami az elnémított, „abnormálisnak”, „gonosznak” ítélt történetek sajátja; a másik pedig a szélesebb értelemben vett traumatizáló tapasztalatoknak az a fajta sajátossága, ami ezeket az élményeket a neurológiai feldolgozás szintjén teszi hozzáférhetetlenné, különválasztva a tudatos, deklaratív memóriától. (Neimeyer, 2006) Ezekben az esetekben a narratíva megalkotásához a nonverbális szimbólumok (Rober, 2002; Seltzer és Seltzer, 1988) vagy a metaforák mint a jelentést szervezô, az érzelmi jelentést, a megélt tapasztalat érzékelési dimenzióit, sôt alapvetô forgatókönyveket magukba sûríteni képes eszközök terápiás alkalmazása nyújt lehetôséget.

\section{A KRÍZISNARRATÍVÁK NYELVI SZERVEZÖI}

\section{Metaforák}

Kézdi szerint a terápiás folyamat lényegében a hibás (nem adaptív) metaforák folyamatos dekonstrukciója (Kézdi, 1998); az állítás a nemzetközi szakirodalomban is bóségesen dokumentált (Battino, 2002; Gergen és McNamee 2000). A metaforák számos sajátossága támasztja alá ezt a megállapítást. A metaforák és az érzelmi jelentés öszszefüggéseire már Davitz (1977) vizsgálata rámutatott. Bár egyes pragmatikai elméletek fényében a metaforahasználatot eleinte közvetett nyelvhasználatnak tekintették (Searle, 1979), a kognitív kutatások fényében az nyert megerôsítést, hogy a metaforáknak, éppen ellenkezóleg, kulcsszerepe van konstrukcióink (ismereteink és a hozzájuk kapcsolódó, élményalapú értékelések) szervezôdésében. Glucksberg és Keysar (1993) 
modelljében a kategorizáció játssza a fôszerepet. A szerzók vizsgálatukban alátámasztották, hogy a metaforikus jelentés képes interferálni a „szó szerinti” jelentéssel, és ez utóbbinak nincs elsóbbsége a feldolgozás során. Lakoff szerint a metafora forrástartomány és céltartomány közötti megfeleltetés, amelyet sajátos strukturális azonosságok vezérelnek (B. Erdôs, 2006; Lakoff, 1993; Rácz és Kaló, 2009). Lakoff számos gyökérmetaforát, bázismegfeleltetést azonosít, amelyeknek segítségével napi tapasztalatainkat megragadjuk ("metaphors we live by"). Metaforákkal fejezünk ki minden olyasmit, amit nem tudunk közvetlenül érzékelni (pl. idő, élet, halál); és metaforákat használunk akkor, amikor a verbalizálandó élmény komplexitása ezt megkívánja, mert a metaforák gondolatot, érzékelést, érzelmet, sốt, akár a mikronarratívákra tett utalásokat egyidejúleg tartalmazhatnak. Többértelmúségük teszi ôket alkalmassá az átmenetekre jellemzô paradoxonok és az ambivalencia megjelenítésére. Az egyedi, nem-konvencionális metafora a not-yet-said verbalizálásában kulcsfontosságú; szokatlansága révén ugyanakkor a befogadót is éberebbé teszi (Paivio és Walsh, 1993). A nem-konvencionális metafora mozgásba hozza a meglévô jelentésszervezôdést, és nyitottá tesz az újra. McNamee (1992) krízismetaforákról írott elemzése szerint válsághelyzetben egyfelôl a határ („peremhelyzet”), másfelôl a zuhanás („verem mélyén”, Bakó, 2004) forrástartományából merítünk a metaforikus megfeleltetéshez - a veszély mellett a kontroll hiánya válik hangsúlyossá (B. Erdôs, 2006).

\section{A negatív kód elmélet és a diszkurzív szuicidológia}

Kézdi Balázs a nyolcvanas évek végén kezdődött kutatómunkája nyomán fogalmazta meg elméletét, amelyet kezdetben a „negatív kód” elméletnek (Kézdi, 1995), késôbb, átfogóbb keretben diszkurzív szuicidológiának (Kézdi, 2003) nevezett. Egyik alapvetô tézise szerint a magyar kultúrában - a kulturális történettár sajátosságai miatt - minden lélektani krízis egyben szuicid krízis is. Ez az erôteljes állítás ellentmondani látszik egyes empirikus vizsgálatok eredményeinek (Kelemen és B. Erdôs, 2003), az ellentmondás azonban részben feloldható, legalábbis átértelmezôdik, ha tekintetbe vesszük Tacey (2005) korábban már idézett koncepcióját, és az öngyilkosságra úgy tekintünk, mint az elözó identitás szimbolikus és az átmenetben szükségszerü „halála” helyett a nyers fizikai valóságban lejátszódó eseményre

Minthogy adott közösség saját kultúráját a szimbolikus kommunikáció, a beszéd, mint kitüntetett jelentôségú társas cselekvés segítségével konstruálja-rekonstruálja (Cohen, 1985; Horányi, 2007), ezért a legkiterjedtebb, specifikusan az emberre jellemzó szimbolikus rendszer, a nyelv vizsgálata jelenti az utat a „kulturális szuicidogén faktor" megismeréséhez (Fekete, 2004; Kézdi, 1987; 1995). Egy ilyen faktor azt is magyarázhatná, miért nem értjük meg idôben az öngyilkosságra készülő segélykérô jelzéseit? A marginalizáció, az egzisztenciális fenyegetettség, a hazánk geopolitikai helyzetéből fakadó történelmi traumák kulturális történettárunk mesternarratívái (László és Fülöp, 2011). Ezek az értékrend polarizációjához vezetnek, élesre húzva a „mi” és az „ók” közötti határvonalakat (Hammack, 2008), megteremtve-eltúlozva a fenyegetettség érzését. Ennek a polarizáltságnak, folytonos egzisztenciális fenyegetettségnek a nyelvi formáit tartalmazza a válsághelyzetek diskurzusa. 
A negatív kód elmélet fontos empirikus alapja, hogy öngyilkossági krízisben a tagadó szerkezetek, illetve az én-re vonatkozó kifejezések száma jelentősen emelkedik (Kézdi 1988; Osváth, Fekete és Tiringer, 2000); ez pontos grammatikai leképezése a lezajló identitásváltozásnak (én nem...). Az én hangsúlyozása a kontroll, az autonómia, a felelôsségvállalás (arányokat tévesztve: búntudat) nyelvi kifejezése (B. Erdôs, 2006; Budwig, 2000). Mind a helyzet kontrollálásának igénye, mind a búntudat jellemzó a krízisállapotra. A tradicionális átmenetek során az én-re helyezett hangsúly fázisról fázisra változik: a liminális, passzív és alázatos Senki és a reinkorporáció centrális, új identitással, általában új nével is felruházott szereplője jelentik ezeket a kontrasztokat (Turner, 2002; Van Gennep, 1960).

Kézdi (1995) elméletében a tagadás szerepét, és különösen a kettôs tagadást alkalmazó grammatikai formákat állította előtérbe. Míg logikai síkon a kettôs tagadás megfeleltethetố egy állításnak, addig a generatív-transzformációs grammatika mély- és felszíni szerkezetrôl, vagy a késôbbi minimalista programnak a megnyilatkozások ökonómiájáról szóló implikációi szerint nem (Surányi, 2009). Többek között Wiener és Mehrabian (1968) hívják fel a figyelmet arra, hogy a közlés strukturálódásának módja, mint metakommunikáció, egy különleges „nyelv a nyelvben”, melynek jelentéséhez inkább érzelmileg viszonyulunk. (Watzlawick, Beavin és Jackson, 1968; Wiener és Mehrabian, 1968). A normatív vagy konszenzuális használattól való eltérés - így például a kettôs tagadás formáját öltô állítás - értelmezésre szorul, a kialakított közvetettség arra utal, hogy a beszélő elkülöníti, eltávolítja magát a mondandójától. A kevéssé elfogadható tapasztalatot és az ahhoz köthetố negatív érzéseket gyakran egy rejtettebb csatornán kommunikáljuk (Wiener és Mehrabian, 1968).

Colston (1999) a tagadás kérdését kísérleti helyzetben vizsgálva az aszimmetria jelenségére hívja fel a figyelmet: míg az emberek többsége a „rossz”-at jelentése alapján nagyjából ekvivalensnek érzi a „nem jó”-val, addig a „nem rossz” távolabb áll a „jó”-tól, mert utóbbi a helyzetre vonatkozó pozitív elvárásokat írja felül. Colston további magyarázata erre az aszimmetriára egy társalgási normán alapszik. Ha valami negatívumot akarunk kifejezni, ritkán tesszük ezt közvetlen formában, ez udvariatlannak minôsülne. Így tehát a pozitív állítás tagadása ugyanazt a szerepet tölti be a társalgásban, mint a közvetlen negatív forma, függetlenül attól, hogy milyen elôzetes elvárások irányítanak bennünket az adott szituációban. Colston kísérleti eredményei szerint a két magyarázat együttesen jut érvényre.

A tagadó szerkezetek elszaporodása mögött a krízishelyzet eltérô szakaszainak sajátosságai fedezhetjük fel: a tagadás jelezhet ambivalenciát, máskor pedig a teljes szituációt érvényteleníti. A tagadásnak ez a két aspektusa Bahtyin (1982) („ambivalens”/ „kronotopikus” vs. „absztrakt”), illetve a Palo Alto-i munkacsoport („disconfirmation” vs. „rejection” (Watzlawick és mtsai, 1968) munkásságában is megjelenik. E kétféle tagadást „ambivalens”, illetve „megsemmisítő” típusnak nevezhetjük. Az ambivalens tagadás a lélektani krízis egy aspektusát (döntés, választás); vagy az elhatárolódást jeleníti meg (Bagdy, 1986), a megsemmisítô tagadás viszont a preszuicidális szindróma (Ringel, 1974) beszúkülésének feleltethetố meg leginkább. Utóbbinál nincs olyan létezô az adott világban, amelyre az elhangzott kijelentés vonatkoztatható; az ilyen megnyilatkozás egy globálisan reménytelennek és zártnak észlelt világot mutat (B. Erdôs, 2006). 


\section{Idöviszonyok}

A krízisnarratívák idôviszonyait két eltérô állapothoz köthetjük. A korábbi narratíva felbomlásával az újrakonstruáláshoz szükség van az idôsíkok egymásra vetítésére. Korábbi tartalomelemzô vizsgálatok megerôsítették, hogy az élettörténeti fordulópontokon az idôperspektíva nemlineáris, a kronológiai idô eltérô síkjai gyors egymásutánban követhetik egymást (B. Erdôs, 2006; Ehmann, 2002; Neimeyer 2000; Pólya, 2014). A belsố narratíva mozgásba lendül. A feldolgozás aktuálisan zajló folyamatát jelzi, ha a beszélô az itt-és-mostra vált (Brown és Bellugi, 1983), a múlt eseményeit jelen idôben mondja el. Mindez az élményt újra közvetlenül átélhetôvé teszi, a többféle kronologikus idô gyors váltakozása a két élmény idôsíkjának egymásra vetítését segíti elő. A küszöb-tér-idô sajátossága, hogy mindhárom idődimenziónak meg kell jelennie benne, mert vissza kell tekinteni a múltba, egyúttal elóre a jövó felé (Stagg, 2014).

Amikor a produktív káoszt a zártság váltja fel, az öngyilkosságot megelőzóen megváltozik az időélmény, azaz „az affektív beszúkülés keretében megáll az idő is, és ez azzal fenyeget, hogy a pillanat örökkévalósággá válik” (Ringel, 1974, 370.) A történetnek nincs jövője.

\section{SZÖVEGELEMZÉS}

Az alábbiakban elemzett beszélgetés egy, a kilencvenes évek közepén lefolytatott OTKA-kutatás (1999-2002: „Az interperszonális távolságszabályozás szimbolikus eszközei” Kézdi Balázs vezetésével) adatbázisának felhasználásával került kiválasztásra. A kutatás során elemzett szövegek (pl. Bernáth, B. Erdōs, Csürke és Kézdi, 2003; B. Erdôs, 2006) egy öngyilkosságmegelốzô sürgôsségi telefonszolgálat oktatási és kutatási célra archivált beszélgetései voltak, amelyeket a telefonszolgálat kutatástól független szakemberei minôsítettek krízishívásnak.

A telefonon keresztül zajló segítô beszélgetés, intervenció sajátos kommunikációs helyzet, ami eltérố munkamódot kíván meg a segítôtôl. Az érzelmi-kapcsolati tartalmak a verbális és vokális kommunikációs csatornán tudnak megjelenni, és a terápiás tér nyitottabb, ezzel a kliens több olyan döntést hozhat meg, amelyek máskor inkább a terapeuta kezében vannak (pl. a beszélgetés kezdeményezése, lezárása). Fontos a folyamatot mindkét fél részrôl befolyásoló projekciók szokatlan intenzitása. Az elsô mondat, az ún., „impressziókeltés” jelentôségét a gyakorló szakemberek jól ismerik, az elsố mondat gyakran sûrítve tartalmazza a kibomló történetet, a problematikát (Balikó, 1990, 2000; B. Erdôs, 2006).

A beszélgetésrészletek egy krízishívás szó szerinti átiratából származnak. A terjedelmi korlátok miatt a telefonbeszélgetésekben gyakori segítôi minimális ösztönzések (ühüm, aha, igen) helyét a sor törésével jelöljük, a kihagyott hosszabb szövegrészek helyére (...) került, ahol feltétlenül szükséges, a tartalmakat röviden összefoglalom. A telefonszolgálatoknál szokásos elnevezéseket (hívó, operátor) a kezdôbetú jelzi, a szöveg anonim. Dólt betûkkel emeltem ki azt, ami ismétlődó elemként a központi konstrukció része, egyben gyakran a negatív koherencia fontos alkotóeleme. 
H: Hát nem is tudom, végül is, én nem öngyilkosjelölt vagyok, akkor is foglalkoznak velem, vagy egyáltalán...

O: Hát persze, persze. Miért, mi a gondja?

$\mathrm{H}$ : Hát nem tudom, végül is, hogy mi a, mi az igazi gondom, csak már hónapok óta gyötrődök rajta, hogy felhívom Önöket. A legnagyobb gondom, azt hiszem, hogy az, hogy azon gondolkodok, már hónapok, talán évek óta, hogy végül is Önök biztos tudják, hogy miért élünk.

Ez biztos, hogy Önöknek van valami ilyen forma, amit elmondanak azoknak, akik, akik úgy érzik, hogy, hogy nincs értelme.

O: aha, és Ön úgy érzi, hogy nincs értelme?

H: Én úgy érzem.

O: Aha, és ez, ez régóta van?

H: Igen.

O: És mi, hogy, hogy kezdődött?

H: Nem tudom.

O: Egyszerüen csak elkezdte így érezni?

H: Igen, és egyre erôsödik bennem ez a, és azt hiszem, hogy félek.

O: Aha, és hogyan él?

H: Hát...

O: Most egyelőre nem azt, hogy miért, hanem hogy hogyan?

H: Hát normál, végül is normálisan élek.

O: Igen. Mit jelent ez a Maga számára, mondjon erról valamit!

H: Hát átlagos család, van férjem, két gyerek, lakás, kocsi, vállalkozók vagyunk, üzleteink vannak, dolgozunk.

(...) hát végül is reggel felkelünk, dolgozunk, este lefekszünk, másnap felkelünk, megint dolgozunk, aztán megint lefekszünk, megint felkelünk és így tovább...

Már a beszélgetés nyitó mondatából következik, hogy krízishívásról van szó, a hívó tudja, hogy öngyilkosságmegelôzô szolgálatot hív, az öngyilkosságra reflektál, önmagát a szituációban ehhez képest határozza meg. Maga a mondat erôs ambivalenciát tükröz. A második mondat megerôsíti ezt az értelmezést: a személyes narratíva integráló funkciója, az, hogy jelentést, célt adjon a személy életének (Hammack, 2008), itt már nem múködik. Az általános érvényú rituális válasz („Önöknek van valami ilyen forma”) keresése mély egzisztenciális válságot sejtet; egy ilyen léptékú változásnál a spiritualitás megélése lehetne a másodfokú változás kerete (Bateson, 1972; Benziman, Kannai és Ahmad, 2012). A hívónak a most létrejövô kapcsolatban nincsenek még saját kimondható szavai arra, ami foglalkoztatja, a belsô történet, a prenarratíva káosza van jelen. Az „átlagos”, a „normális” annál is zavarba ejtôbb, mert a kulturális történettár nem kínál olyan gyors és egyértelmú magyarázatokat az átélt szenvedésre, mint akcidentális krízisek esetében. A mélypont (nadir) jellegzetes tapasztalatai a halál, a betegség, a veszteség (Stagg, 2014). Ha valaki „normális” helyzetben boldogtalan, az „nem normális”. A kimondható, az elbeszélt, a kulturálisan konform a hétköznapi élet része: ami ezen túl van, az az antistruktúra kaotikus, a hétköznapok rendjéból értelmezhetetlen világához tartozik. A mélypont lényegi vesztesége, tapasztalata azonban éppen a ki- 
számítható és biztonságos világ elvesztése. Megkérdôjelezôdik az, amiben a személy korábban hitt, amit biztosra vett; mindez az erótlenség, üresség érzésével jár együtt (Stagg 2014).

A hívó elmondja, hogy vállalkozásukat a semmibôl, fôként az ô ügyességére és kitartására építve hozták létre és múködtetik; szívesen végzi az ebben adódó számos feladatot, míg vele együtt dolgozó férje szerepe korlátozott. Munkájuk nagyon eredményes, a vállalkozás folyamatosan gyarapszik. Házasságuk - a hívó második házassága - 17 éve tart. Elsô házasságát „túl fiatalon”, szerelemből kötötte, elsô férjével a gyors válás után baráti viszony maradt fenn. Második házassága „nem volt ilyen mély érzelem”, megfontoltabban döntött, biztonságos kapcsolatot keresett, vonzotta férje akkori munkaszeretete. Második férje azonban inni kezdett, nem vállal felelósséget, ugyanakkor túlzó anyagi igényekkel lép fel, nagyképú („az italtól egyre inkább leépül az agya”, „nem igazán érdekel, ha berúg”). Két fiával jó a kapcsolata.

O: 17 éve? És milyen, milyen a kapcsolatuk?

H: hát, az nem valami jó, hát, szóval, ez megint azt mondhatom, hogy átlagos, szóval, hát mint minden...

minden családban.

O: Mit ért ez alatt?

H: Van olyan nap, hogy, úgy, úgy nagyon jó kedve van az embernek és nagyon jól kijön a másikkal, és van olyan idôszak, amikor annyira gyülöli, hogy meg tudná fojtani. Énszerintem minden, minden házasságban van ilyen.

O: Hát tudja, én nem nagyon tudom, hogy mi az, hogy átlagos.

Érdemes megfigyelni a nyelvi közvetettség („az embernek”, „minden”) magas fokát; és azt, ahogyan a not-yet-said, a ki nem mondott, a belsố történet megalkotására a terapeuta „not knowing” attitúdje a válasz (Kelemen, 2011; Rober, 2002). Ellentmondás feszül az „átlagos” élet és az extrém, gyilkos düh feszültsége között.

Ezt követôen a hívó elmondja, hogy haragot és irigységet érez férje iránt, aki a vállalkozás múködtetésének terheibôl nem veszi ki a részét („nagyon, nagyon jó élete van”), nem vállalja a felelősséget („mindig én kezeltem a dolgokat”; „azt hiszem, hogy ô erre alkalmatlan").

H: De szóval, az az igazság, hogy, hogy nem is annyira tanácsot kérnék, én inkább csak úgy szeretném elmondani, hogy...

O: igen, mondja!

H: annyira fáj, szóval az ember nemcsak anyagilag vagy testileg lehet nyomorék. Az ember lelkileg is teljesen nyomorék lehet egy idô után.

Meg én úgy érzem, mintha a férjem egy elmebeteg lenne, és egy

O: Tényleg?

$\mathrm{H}$ : elmebeteggel kellene együtt élnem.

(...) óvele nem lehet két értelmes mondatot elbeszélgetni. 
Nem lehet azt mondani, hogy figyelj, gyere, üljünk le, és neked mi lenne a véleményed arról, hogy én ezt most így csinálnám, vagy úgy csinálnám, mert egyszerúen nem válaszol

egyszerúen nem válaszol, és kihoz a sodromból annyira, hogy

O: akkor kiabálna vele

H: Nem, nem. Ez a legnagyobb baj, hogy se üvölteni nem tudok, se, se, sírni azt tudok, de nem úgy, hogy elôtte, mert hát végül is ốt ez nem érdekli. Se üvölteni, se az, amit másutt hallom, hogy a tányért a földhöz vagdal, meg

ilyesmire, én ezt nem tudom, mert én akkor elvonulok, és akkor, akkor magamban elgondolom, hogy, hogy mennyire szerencsétlen vagyok.

$\mathrm{H}:$ (...) most elmondtam, és mondja, hogy igen, megértette, és igazam van, és így, és másnap ugyanazt csinálja, ugyanazt, mintha, mintha, mintha nem is beszéltünk volna róla.

H: Úgyhogy az utóbbi idóben már nem is mondok neki semmit.

A hívó leírásából kibontakozó, általa észlelt mintázat megegyezik az alkoholbetegek szimmetrikus kommunikációs mintázatával, az érzelmi tartalmak iránti érzéketlenségével („ezt most miért ide irtad? „ez miért öt, miért nem kilenc? „mindenkire támad egyfolytában”) (Amenta, Noël, Verbanck és Campanella, 2013; Bateson, 1972). A ki nem mondott tartalmak és az ezekkel járó érzelmi feszültség fokozatosan gyúlik, a düh megreked. Felvetôdik a kérdés, hogy miképpen lett néma ez a hosszú ideje szövôdô belsô történet?

O: (...) és mondja, akkor ezek szerint a gondjait kivel szokta megosztani?

H: Kivel?

O: Barát?

H: Senkivel, hát...

(ezt követôen a hívó elmondja, hogy édesanyja él a közelükben, de rá nem tud támaszkodni):

H: Nem akarok, mert ô, ô még tehát, hogyan mondjam, ô, ô úgy vigasztal engem, hogy, hogy még jobban szid.(...) Tehát akkor még jobban hergel engem (...) neki, anyukámnak annyira fáj, hogy hetekig szinte belebetegszik.

Így tehát a hívó a néma gyerek, akinek anyja sem érti a szavát: néma, mert a korai kapcsolatban feltehetôleg azt tanulta meg, hogy el kell némítania saját dühét és fájdalmait, hiszen ezek egy „átlagos” élet hétköznapjainak velejárói. Ha nem így tesz, ha nem ôrzi magában a fájdalmat és a dühöt, a negatív érzések kontrollálatlanul kiáradnak, és megbetegíthetik azt, aki neki fontos (=gátolt és befelé forduló agresszió). A belsô történet tehát nem néma, hanem elnémított. Ez a belsố történet keresi azt a hangot, amelyen megszólalhat: a belsố történet elmondására a reflektív szelf egy dialogikus folyamatban válhat képessé.

H: „én, én nem ôt hibáztatom mindenért, én, énnekem az fáj, hogy ô nem segít nekem. Tehát ezért hibáztatom talán. Magamban, tudat alatt, talán ezért támadok rá, mert úgy érzem, segíteni kellene, ha baj van. (...) olyan, mint egy gyerek, és oda is so- 
rolja magát a gyerekek közé (...) most elmondtam, és mondja, hogy igen, megértette, és igazam van, és így, és másnap ugyanazt csinálja,

ugyanazt, mintha, mintha, mintha nem is beszéltünk volna róla,

úgyhogy az utóbbi idôben már nem is mondok neki semmit.

A család bezárkózik, barátok nincsenek, a pihenés, szórakozás elmarad, a férfi italozása, a nô részéról a munka és - újabban - a fojtogató betegség tölti ki a kiüresedett kapcsolatot:

H: és ó mondta, hogy mindig azt mondtam, hogy addig nem halunk meg, amíg nem láttam Párizst és a piramisokat (...) miért nem megyünk el tényleg? hogy tudja, hogy, hogy ez az életem álma volt. Mondtam, hogy már nem, már nem megyek.

O: hogy már ahhoz sincs kedve

H: Már nem akarom látni.

Már nem érdekel (...) Különösen vele egyáltalán nem érdekel.

(...)

O: És azt el tudná képzelni, hogy egyedül?

H: Nem.

O: Azt sem?

H: Nem. Nagyon, nagyon gyáva vagyok (...) hogyha Ön énvelem találkozna holnap délelốtt az utcán, nem tudná, hogy én ki vagyok, akkor azt mondaná, azt, azt gondolná magában, hogy ez egy határozott, egy, egy olyan nô, aki tudja, hogy mit akar. (...)

A nyilvános szelf elbeszélt története elválik a megélt és a formálódóban lévô belsô történettôl, ez a dezintegráció a narratíva rekonstrukcióját teszi szükségessé.

H: (...) de hát egyszerúen most táppénzen is vagyok a jelen pillanatban, mert már, már teljesen, szóval orvosnál is voltam (...) végül is azt állapították meg, mert küldtek vizsgálatokra, hogy idegi alapon, tehát nem tudnak csinálni semmit.

O: aha, és mi volt, mi a panasza?

$\mathrm{H}$ : Az, hogy annyira fulladtam, úgy éreztem, hogy megfojt valami (...) azelôtt nem voltam soha orvosnál (...) ilyen erôteljesen, tehát tényleg úgy éreztem, hogy megfulladok (...) egyszerúen, nem, nem bírtam nyelni, és akkor nem találtak semmit (...) nyugtatót kaptam, most már csak, elôször még a vizsgálat elôtt írt a háziorvosom gyógyszert, mert mondtam neki, hogy én nem fogom tudni kivárni a vizsgálat végét, mert én addigra meg fogok fulladni.

Az el nem mondott történet, a ki nem mondható, szimbolikus eszközökkel meg nem jeleníthetô, de többé le sem nyelhetô fájdalom és düh mint testi tünet fejezôdik ki. Az átmenet szimbolikus minôségei, pszichológiai tartalmai hitelesítô, elfogadó kapcsolat híján nyers, fizikai síkon jelennek meg. A „nem tudnak csinálni semmit” tehetetlenségében ugyanakkor az is megjelenik, hogy ez a tünet fontos a hívó számára, nem lehet tôle csak úgy egyszerúen „elvenni”. A nyugtatót a hívó nem tekinti gyógyszernek: „nyugtatót kaptam, most már csak.” Az egzisztenciális válságot, a „miért élünk” kérdésének feszültségeit, szenvedését egy betegség legitimálja. Ismert, hogy az öngyilkosság- 
ra készülő személyek nagyon nagy arányban keresték fel háziorvosukat, ezt egyfajta cry-for-help viselkedésként értelmezhetjük (Luoma, Martin, Pearson, 2002). Megerôsíti ezt az értelmezést az alvásra tett alábbi utalás: a hosszú alvás utáni vágy - amit alább a szövegben a többszöri ismétlés hangsúlyoz - hasonló kontextusban az öngyilkosság egy bázismetaforája.

H: Aludni, azt tudnék.

Szerintem hetekig.

Szerintem hetekig tudnék aludni (...)

(...)

O: Én úgy gondolom, hogy ezek a lelki bajok, ezek legalább olyan nehezek tudnak lenni.

H: Hát pontosan én is ezért gondolkodtam, hogy telefonálok, mert, úgy mondom, hogy hónapok óta gyötrôdök rajta, hogy telefonáljak, ne (...) hiszen vannak olyan emberi nyomorúságok, hogy amellett az én bajom, az, az eltörpül. De végül is mindenki maga érzi a saját...

O: Ezt én is így gondolom.(...)

H: Én tudom, hogy mi a megoldás, de én azt úgyse fogom megtenni.

O: Miért, mi a megoldás?

H: Azt kellene, hogy elválni (...) Nagyon régóta gondolkodom rajta (...) Tehát építettük az üzletet.

És akkor kezdett bele a férjem az ivásba. De akkor olyan mértékben, hogy az ájulásig.

Volt úgy, hogy másfél liter pálinkát megivott, és hát valósággal, hát úgy nézett ki, hogy itt fullad meg a konyhában a szemem láttára (...) én erre az idôpontra teszem azt, amióta ô egyre inkább leépül (...) ô nem alkoholista, azt mondja.

És most is beteg voltam, hát ugye, sorba jöttek a telefonok, mit mondott az orvos, mi van, hogy hová kell menned (...) egyes egyedül a férjem nem kérdezte meg egy mocskos szóval se, hogy figyelj, hát mit mondott az orvos (...) bármi, bármi, egy emberrel történhet baleset, betegség, az én férjem nem kérdezi meg tólem, hogy figyelj, Te miért fekszel ott egy hete? (...) hát az ember egy idegentôl megkérdezi (...) és kérdezi, hát Te hová mész? (...) és akkor, akkor tört ki, szóval akkor elkezdtem tényleg sírni, és mondtam , hogy nem baj, hogy nem kérdezted meg, mert tíz-tizenöt idegen megkérdezte tôlem. (...) még az is lehet, hogy ố nem rosszindulatból nem kérdezte meg, hanem talán anynyira buta, hogy, hogy eszébe se jutott, hogy megkérdezze. (...) néha nagyon csúnyán beszélek tényleg, mert, mert néha, már nem úgy, hogy csúnya szavakat, mert az nem szokásom, de volt, már, amikor azt mondtam, hogy ki kötelez engem arra, hogy egy elmebeteggel éljem le az életem?

És ki? az vesse rám az elsố követ, aki, aki ezt meg tudja csinálni.

O: Hm, mert úgy gondolja, hogy ez egy olyan dolog, már hogy a válásra gondol, hogy ezért, szóval elítélik, vagy maga elítéli magát, vagy...

$\mathrm{H}$ : Nem, tehát, tehát a válással kapcsolatosan

O: mert azt mondta, hogy soha nem tenné meg

H. Soha nem tenném meg, nem azért, mert elítélem magam. Ehhez én nagyon gyáva vagyok. Tehát az előbb ott hagytuk abba, hogyha találkoznánk az utcán, akkor kezdtem el ezt, 
hogy, hogy én ehhez nagyon gyáva vagyok. Én nem tudnék egyedül élni.

tehát én nagyon, nagyon félek attól, hogy egyedül maradok, azt, azt egyszerúen nem tudnám elképzelni, hogy egyedül éljek.

O: Hát azt nehéz is ennyi évi házasság után, de hát valahogy így sem jó az élete.

H: Nem, nem, nem, tehát egyszerúen tudom, hogy ezt kellene tennem, én tisztában vagyok vele, de nem, nem, nem fog menni soha az életben, szerintem ezt ô is tudja. (...)

H: Más, más megoldás nincs. Vagy ezt így eltúröm, amíg élek, vagy nem. (...) és ez, tehát olyan kutyaszorító.

Az operátor (a törôdô idegen; B. Erdôs, 2006) a hiányzó hitelesítést, elfogadást adja, és ezzel lehetôvé teszi a ki-nem-mondott, „,súnya”, „mocskos” tartalmak elbeszélését, és a cselekvést ellehetetlenítő, a kapcsolati dinamikából következó kutyaszorító, az egykori kettôs kötés nyomán a párkapcsolatban újjáteremtett csapda leírását.

A következôkben az operátor összegzi az eddig elhangzottakat, hangsúlyozva, hogy a hívó fontos, a változás felé mutató lépést tett a segítségkéréssel, és „úgy mutatta be magát, mint aki, hát aki csodákra képes”. Bátorítja további, face-to-face terápiás segítség igénybe vételére, a kiút keresésére.

H: de hát, de hát, amit elhatározok, azt én mindent véghezviszek.(...)

O: igen, hát azért gondolom, hogy nagyon kínzó lehet, és hát tényleg érzem, hogy szeretne ezen, erre valami megoldást találni.

H: Úgy érzem, mintha leindultam volna én is egy hülyülés útján, tehát múltkor pont azt kérdeztem ettôl a barátnômtôl, hogy hülyül meg egy ember, tehát hogy hogyan jut el oda, hogy teljesen megbomlik az agya. Mert én úgy érzem, hogy egy ilyen útra jutottam el. (...) kiesnek gondolatok az agyamból (nem emlékszik a közelmúlt eseményeire).

Kiesnek gondolatok az agyamból.

(...) Nem tudom. Mindig azt gondoltam magamban, hogy negyven éves korig talán érdemes élni. (...) És akkor elgondoltam, hogy

O: Szóval ilyenre is gondolt már, hogy öngyilkos lesz.

H: Hát igen, gondoltam rá, és már mindent végiggondoltam, hogy milyen módon, csak, csak ehhez is gyáva vagyok, tehát mindenre csak ezt tudom mondani, hogy gyáva vagyok. Mert elgondoltam, hogy kiugrok az ablakon, az ötödik emeletrôl jó nagyot lehet esni, és hogyha véletlenül nem halok meg, akkor mi lesz?

A beszúkülés tapasztalata sajátos módon tükrözi vissza a párkapcsolati problematikát (elmebeteggel élni - megbomlik az agya). Jellegzetes és ismétlődô elem az élet tartamára vonatkozó kontrollmozzanat (=meddig érdemes élni? Párizst látni és azután meghalni? negyven éves korig?). Az öngyilkossági tervek irracionalitása, szimbolikus üzenete mutatkozik meg abban, hogy a hívó felfogásában öngyilkosságra csak a saját otthonának az ablaka „alkalmas”. A beszélgetésben emlegetett kitartó határozottság (a gyávasággalbátorsággal összefüggésben is) ebben a kontextusban kifejezetten vészjósló.

H: Akkor elgondoltam, hogy a vonat alá fekszek, hát, ez most már röhej így utólag elmondani, mert biztos, hogy nem fogom megtenni, szóval biztos. De hát gondoltam, vonat alá fekszek. 
Igen ám, de mi lesz, ha nem a fejemet vágja le, hanem a lábamat, tehát ilyen hülyeségeken gondolkodok, hogy például, az borzalmas, a mélység, az nagyon vonz

úgyhogy az erkélyre már legalább két éve nem mentem ki,

Hát egyszerüen, ha lenézek, akkor abban a pillanatban eljön az az érzésem, amit mondtam, hogy kiesek ebból a világból, és akkor arra gondolok, hogy, hogy csak egy másodperc kell, amíg kilépek (...) szóval oly mértékben belebetegedtem, amit nem is tudok elmondani, hogy néha úgy érzem, mintha kiesnék ebból a világból, mint hogyha lebegnék, és ezt elmondtam az, az orvosnak is, már a háziorvosnak (...)

(Sok minden összejött, apró bosszúságok is. Az operátor megerôsíti a segítségkérés fontosságát.)

Még úgy érzem, hogy, hogyha nem rám támaszkodna valaki, hanem én támaszkodhatnék valakire,

akkor tényleg, ahogy mondja, csodákra lennék képes.

(A felek megegyeznek a másnapi kapcsolatfelvételben, amit az operátor közvetít a terapeuta felé.)

A beszélgetés elején általánosságban említett és tagadott öngyilkosságról kiderül, hogy a hívó belsố történetének visszatérô eleme. A tünetek nyelvén megfogalmazódik a liminális, köztes tapasztalat jellegzetessége („lebegés”). Az életet paradox módon ugyanaz a "gyávaság" - egy hasznosnak bizonyuló fóbia (Bereczkei, 2003) - menti meg, mint ami meggátolja a fejlódést, az előrelépést, az autonómia kibontakoztatását.

\section{ÖSSZEGZÉS, MEGVITATÁS}

Az identitás változása a narratíva változása: krízishelyzetben nem csupán egy állapot nyelvi jeleirôl, hordozóiról van szó, hanem a nyelv használata, a beszéd mint cselekvés egyben a változás módja, ahol a korábbi koherencia, az értelmezések, oksági láncolatok (McAdams, 2006) felbomlása a változás kiindulópontja. Az elbeszélt, nyilvánosan megjelenített, de már nem hiteles és nem hitelesíthetô narratíva mögött felsejlô belsô narratíva konstrukciói képlékenyek, bizonytalanok, ambivalensek.

Mindez a szöveg szintjén a tagadó szerkezetek mindkét típusának az elszaporodását vonja maga után. A krízisnarratívák szervezôdésben továbbá kulcsszerepet játszanak a sajátos, a halállal, megszúnéssel, életveszéllyel, újjászületéssel kapcsolatos, az élmény teljességét, a belsố folyamatokat reprezentáló, ugyanakkor a kulturális történettárból is merítô metaforák. A tudatos átélés és kontroll megszúnése, a káosz megfelelôje a hosszú alvás, illetve a megbolondulás. Az esés, zuhanás mint elsô gravitációs tapasztalat a születésünkhöz köthetô, így a nagy léptékú változások, az újjászületés kockázatos élményének megragadására ez a bázismetafora kifejezetten alkalmas. A normális, de kaotikus, fájdalmas és szorongató tapasztalatot az eredeti környezet ismétlôdô jelleggel sem hitelesíti, ezzel elzárja a kommunikáció lehetôségét. A belsô narratíva kimondatlansága-kimondhatatlansága mögött a korai tapasztalatok, a kettôs kötés $k u$ tyaszorítója van jelen. A fojtogató kapcsolatokban „nyelni” kell a „gyávaság”, a korai kötôdésekben beépülô szorongások és búntudat miatt; és beteggé is kell lenni akkor, ha a „semmi” okozza a problémákat; hátha ennek révén az átélt szenvedés értelmezhetôvé 
és hitelesíthetôvé válik. A kötôdés zavarai, a határproblematika jól megmutatkozik a tünetek nyelvén: visszhangzó, de nem reflektált tapasztalat a házastársak közös „elmebetegsége" és "fulladása”.

A normális káosz patológiává, betegséggé alakul, és megjelennek az öngyilkosságról szôtt fantáziák, képzetek; egyúttal megjelenik az életet védô fóbiás tünet. A segítô legfontosabb szerepe, hogy hitelesítse a kapcsolati válság nyomasztó voltát, és segítségével a hívó alternatív magyarázatokat alakítson ki saját állapotáról; majd ezek birtokában alternatívákat fogalmazhasson meg saját jövôjére nézve. A csodák megélésére és a saját képességek újbóli felfedezésére ebben a hétköznapok világán túlmutató átmeneti kontextusban szükség van; a „normális” élet nem hatékony ellensúlya, hanem kerete a megélt mély szenvedésnek. Krízisben a jelentések erôs polarizáltsága éppen ehhez a nem hétköznapi, mitikus világhoz köthetô.

\section{IRODALOM}

Amenta, S., Noël, X., Verbanck, P., \& Campanella, S. (2013). Decoding of Emotional Components in Complex Communicative Situations (Irony) and Its Relation to Empathic Abilities in Male Chronic Alcoholics: An Issue for Treatment. Alcoholism: Clinical and Experimental Research, 37(2), 339-347.

Anderson, H., \& Goolishian, H. A. (1988). Human Systems as Linguistic Systems: Preliminary and Evolving Ideas about the Implications for Clinical Theory. Family Process, 27, 371-393.

Angus, L., Levitt, H., \& Hardke, K. (1999). Narrative processes and psychotherapeutic change. Journal of Clinical Psychology, 55, 1255-1270.

B. Erdôs, M., Csürke, J., Kézdi, B., \& Bernath, L. (2002). Openings and endings of encounter-type conversations (Content analysis) VI. Alps Adria International Conference, Rovereto, 2002. okt. 3-5, abstract: 57.

B. Erdôs M. (2006). A nyelvben élō kapcsolat. Pécs: Typotex.

B. Erdôs, M., \& Kelemen, G. (2011). The Finite Universe: Discursive Double Bind and Parrhesia in State Socialism. History of Communism in Europe, 2, 281-309.

Bagdy E. (1986). Családi szocializáció és személyiségzavarok. Budapest: Tankönyvkiadó.

Bahtyin M. (1982). François Rabelais müvészete, a középkor és a reneszánsz népi kultúrája. Budapest: Európa Kiadó.

Bakó T. (2004). Verem mélyén. Budapest: Psycho Art.

Balikó M. (1990). Tele/pszicho/fon. Budapest: Animula.

Balikó M. (2000). Az impressziókeltés kommunikációs sajátosságai vokális csatornán keresztül. I-II. In Kelemen G. (szerk.), Tele-dialógus (pp. 98-133). Pécs: Pro Pannonia.

Bateson, G. (1972). Steps to an Ecology of Mind: Collected Essays in Anthropology, Psychiatry, Evolution, and Epistemology. Chicago: University of Chicago Press.

Battino, R. (2002). Metaphoria: Metaphor and guided metaphor for psychotherapy and healing. London: Crown Publishing House.

Benziman, G., Kannai, R., \& Ahmad, A. (2012). The Wounded Healer as Cultural Archetype. Comparative Literature and Culture 14 (1). Letöltés: 2017. 06.25. http://docs.lib.purdue.edu/ cgi $/$ viewcontent.cgi? article $=1927 \&$ context $=$ clcweb

Bereczkei, T. (2003). Evolúciós pszichológia. Budapest: Osiris.

Brown, R., \& Bellugi, U. (1983). Három folyamat a szintaxis elsajátításában. In Pléh Cs. (szerk.), Szöveggyüjtemény a pszicholingvisztika tanulmányozásához (pp. 395-416). Budapest: Tankönyvkiadó. 
Bruner, J. (1990). Acts of Meaning. The Jerusalem-Harvard Lectures. Cambridge: Harvard University Press.

Budwig, N. (2000). Language and the construction of self. Linking forms and functions across development. In N. Budwig, I. C. Uzgiris, \& J. Wertsch (Eds), Communication: an arena of development (pp. 195-214). Greenwich, CT: Ablex.

Bussolari, C. J., \& Goodell, J. A. (2009). Chaos Theory as a Model for Life Transitions Counseling: Nonlinear Dynamics and Life's Changes. Journal of Counseling, Development, 87, 98-107.

Caplan, C. (1964). Principles of Preventive Psychiatry. New York: Basic Books, Inc.

Cohen, A. (1985). The Symbolic Construction of Community. London: Tavistock.

Colston, H. L. (1999). "Not Good" Is "Bad" but "Not Bad" Is Not "Good": An Analysis of Three Accounts of Negation Asymmetry. Discourse Processes, 28(3), 237-256.

Davitz, R. (1977). Az érzelmi jelentés. In Horányi Ö. (szerk.), Kommunikáció 1-2. (pp. 139-153). Budapest: Közgazdasági és Jogi Kiadó.

Ecker, B., \& Hulley, L. (2000). The Order in Clinical "Disorder": Symptom Coherence in Depth-oriented Brief Therapy. In R. A. Neimeyer, \& J. D. Raskin (Eds), Constructions of Disor$\operatorname{der}$ (pp. 63-89). Washington: APA.

Erikson, E. H. (1968). Identity: Youth and Crisis. New York: Norton.

Fekete S. (2004). Öngyilkosság és kultúra. Budapest: Új Mandátum.

Festinger, L. (2000). A kognitív disszonancia elmélete. Budapest: Osiris Kiadó.

Foucault, M. (2000). Elmebetegség és pszichológia. A klinikai orvoslás születése. Budapest: Corvina.

Gergen, K. J., \& Gergen, M. M. (1983). Narratives of the Self. In T. R Sarbin, \& K. E. Scheibe (Eds), Studies in Social Identity (pp. 254-273). New York: Praeger.

Gergen, K. J., \& McNamee, S. (2000). From disordering discourse to transformative dialogue. In R. A. Neimeyer, \& J. D. Raskin (Eds), Constructions of disorder: Meaning-making frameworks for psychotherapy (pp. 333-349). Washington: APA.

Glucksberg, S., \& Keysar, B. (1993). How Metaphors Work. In A. Ortony (Ed.), Metaphor and Thought (pp. 401-424). Cambridge: Cambridge University Press.

Grof, S. (1988). The Adventure of Self-Discovery. Dimensions of Consciousness and New Perspectives in Psychotherapy and Inner Exploration. Albany: SUNY Press.

Hammack, P. L. (2008). Narrative and the Cultural Psychology of Identity. Personality and Social Psychology Review, 12(3), 222-247.

Hanninen, V. (2004). A model of narrative circulation. Narrative Inquiry, 14(1) 69-85.

Harré, R. (1998). The singular self. London: Sage.

Harré, R. (2004). Discursive Psychology and the Boundaries of Sense. Organization Studies, 8, $1435-1453$.

Horányi Ö. (2007). A kommunikáció participációra alapozott felfogásáról. In Horányi Ö. (szerk.), A kommunikáció mint participáció (pp. 246-264). Budapest: AKTI-Typotex.

Hyden, L. C. (1995). The rhetoric of recovery and change. Culture, Medicine and Psychiatry, 19, 73-9).

Johnson, T. J., Pfenninger, D. T., \& Klion, R. E. (2000). Constructing and Deconstructing Transitive Diagnosis. In R. A. Neimeyer, \& J. D. Raskin (Eds), Constructions of Disorder (pp. 145-173). Washington: APA.

Kelemen, G., B., \& Erdôs, M. (2003). The role of reintegration rituals in sobriety: A comparative study on recovery and relapse. Dynamic Psychiatry, 36, 89-113.

Kelemen, G., B. \& Erdős, M. (2004). Craving for Sobriety. A Unique Therapeutic Community in Hungary. Pécs: The Faculty of Humanities, University of Pécs and The Leo Amici Foundation.

Kelemen, G. (2011). Átlendülés - Vázlatok a reflektív klinikai szociális munkához. Budapest: Animula.

Kelly, G. (1955). The psychology of personal constructs. New York: W. W. Norton, Company. 
Kézdi B. (1988). Tagadás és öngyilkosság. Psychiatria Hungarica, 3(1), 15-23.

Kézdi B. (1995). A negatíu kód. Pécs: Pannónia Kiadó.

Kézdi B. (1998). Márai metaforái. Pannonia Pszichiátriai Egyesület DREAM konferencia. 1998. december 16., Pécs.

Kézdi B. (2003). A kulturális pszichológia hozzájárulása a szuicidológia diszkurzív paradigmájának kialakulásához. In Kállai J., \& Kézdi B. (szerk.), Új távlatok a klinikai pszichológiában (pp. 7-11). Budapest: Új Mandátum.

Lakoff, G. (1993). The Contemporary Theory of Metaphor. In A. Ortony (Ed.), Metaphor and Thought (pp. 202-252). Cambridge: Cambridge University Press.

László J. (2005). A történetek tudománya. Bevezetés a narratív pszichológiába. Budapest: Új Mandátum.

László J., \& Fülöp É. (2011). Nemzeti identitás és kollektív áldozati szerep. Pszichológia, 31(3), 295-315.

Luoma, J. B., Martin, C. E., \& Pearson, J. L. (2002). Contact with mental health and primary care providers before suicide: a review of the evidence. American Journal of Psychiatry, 159(6), 909-916.

Mahoney, M. J. (2000). Core Ordering and Disordering Processes: A Constructive View of Psychological Development. In R. A. Neimeyer, \& J. D. Raskin (Eds), Constructions of Disorder (pp. 43-62). Washington: APA.

Maruna, S., Wilson, L., \& Curran K. (2006). Why God Is Often Found Behind Bars: Prison Conversions and the Crisis of Self-Narrative. Research in Human Development, 3(2-3), 161-184.

Máthé-Tóth A. (2011). Vallási kommunikáció és vallásdiskurzus. PhD-disszertáció. Pécs: Pécsi Tudományegyetem.

McAdams, D. P. (2006). The problem of narrative coherence. Journal of Constructivist Psychology, 19(2), 109-125.

McNamee, S. (1992). Introducing, Reconstructing Identity: the Communal Construction of Crisis. In S. McNamee, \& K. J. Gergen (Eds), Therapy as Social Construction (pp. 187-200). London: Sage.

Mead, G. H. (1973). A pszichikum, az én és a társadalom. Budapest: Gondolat.

Neimeyer, R. A. (2000). Narrative Disruptions in the Construction of the Self. In R. Neimeyer, \& J. Raskin (Eds), Constructions of Disorder (pp. 207-241). Washington: APA.

Neimeyer, R. A. (2006). Re-Storying Loss: Fostering Growth in the Posttraumatic Narrative. In L. Calhoun, \& R. Tedeschi (Eds), Handbook pf Posttraumatic Growth. Research and Practice (pp. 67-80). Mahwah, NJ: Lawrence Erlbaum.

Osváth P., Fekete S., \& Tiringer I. (2000). Szuicídium és szöveg. Búcsúlevelek transzkulturális szempontú elemzése magyar-angol-német anyagban. In Kelemen G. (szerk.), Teledialógus (pp. 143-156). Pécs: Pro Pannonia.

Paivio, A., \& Walsh, M. (1993). Psychological Processes in Metaphor Comprehension and Memory. In A. Ortony (Ed.), Metaphor and Thought (pp. 307-328). Cambridge: Cambridge University Press.

Pikó B (2002). Adalékok a mentális zavarok kritikai szociológiájához. Szociológiai Szemle, 2, 99-113.

Poal, P. (1990). Introduction to the Theory and Practice of Crisis Intervention. Quaderns de Psycologica, 10, 121-140.

Pólya T. (2014). Múltbeli érzelmek újraélése és a történetek idôi szervezôdése. In Boros G., \& Pólya T. (szerk.), Szenvedély, szerelem, narrációk (pp. 176-187). Budapest: ELTE Eötvös Kiadó.

Rácz, J., \& Kaló, Zs. (2009). Metaforák és pszichoaktív anyaghasználat. Korunk. Letöltve: 2017.08.14. http:/ /www.korunk.org/?q=node/8\&ev=2009\&honap=7\&cikk=10870. 
Ringel, E. (1974). A preszuicidális szindróma (öngyilkosság elốtti tünetcsoport) tünettana. In Andorka R., Buda B., \& Füredi J. (szerk.), A deviáns viselkedés szociológiája (pp. 367-381). Budapest: Gondolat.

Rober, P. (2002). Constructive hypothesizing, dialogic understanding, and the therapist's inner conversation. Some ideas about knowing and not knowing in the family therapy session. Journal of Marital and Family Therapy, 28(4), 467-478.

Searle, J. R. (1979). Expression and Meaning. Cambridge: Cambridge University Press.

Seltzer, W. J., \& Seltzer, M. R. (1988). Culture, Leave-Taking Rituals and the Psychotherapist. In Onno Van der Hart (Ed.), Coping with Loss. The Therapeutic Use of Leave-Taking Rituals (pp. 171-200). New York: Irvington Publishers.

Smith, J., A. (2002). Suicide in Post-Socialist Countries. Examples from Hungary and Belorus. The Anthropology of East Europe Review, 20(1), 55-65.

Smith, B., \& Sparkes, A. C. (2008). Contrasting perspectives on narrating selves and identities: an invitation to dialogue. Qualitative Research, 8(1), 5-35.

Stagg, R. (2014). The Nadir Experience: Crisis, Transition and Growth. The Journal of Transpersonal Psychology, 40(1),72-91.

Surányi B. (2009). Probléma-eltolódások a chomskyánus nyelvészetben. A generatív nyelvészet ma. Magyar Tudomány. MTA. Letöltés: 2017.08.30. http://www.matud.iif.hu/2009/09sze/06. htm.

Tacey, D. (2005). Spiritual perspectives on suicidal impulses in young adults. In R. H. Cox, B. Ervin-Cox, \& L. Hoffman (Eds), Spirituality and psychological health (pp. 107-128). Colorado Springs: Colorado School of Professional Psychology Press.

Turner, V. (1982). From Ritual to Theatre. New York: PAJ Publications.

Turner, V. (2002). A rituális folyamat. Struktúra és antistruktúra: a Rochesteri Egyetemen (Rochester, New York) 1966-ban tartott Lewis Henry Morgan-elóadások. Budapest: Osiris.

Van Gennep, A. (1960). The Rites of Passage. Chicago: University of Chicago Press.

Vigotszkij, L. Sz. (1967) Gondolkodás és beszéd. Budapest: Akadémiai Kiadó.

Watzlawick, P., Beavin, B, \& Jackson, D. (1968). Pragmatics of Human Communication. London: Faber and Faber.

Watzlawick, P., Weakland, J. H., \& Fisch, R. (1990). Változás. A problémák keletkezésének és megoldásának elvei. Budapest: Gondolat.

Weinreich P. (2003). Identity Structure Analysis. In P. Weinreich, \& W. Saunderson (Eds), Analysing identity: Cross-cultural, societal and clinical contexts (pp. 7-76). London: Routledge, Psychology Press.

Weinreich, P. (2010). A Guide to the Generation of a Well-Constructed Instrument . Letöltve: 2015.11.15. http://www.identityexploration.com/uploads/files/ISA_identity_instrument_guide.pdf.

White, W. L. (1996). Pathways from the culture of addictions to the culture of recovery. Center City, MN: Hazelden.

White, M., \& Epston, D. (1990). Narrative means to therapeutic ends. New York: W. W. Norton.

Wiener, M., \& Mehrabian, A. (1968). Language within language: Immediacy, a channel in verbal communication. New York: Appleton-Century-Crofts. 


\section{„...I FEEL AS IF I FELL OUT OF THIS WORLD.” NARRATIVE CHARACTERISTICS OF THE TRANSITIONAL EXPERIENCES OF PSYCHOLOGICAL CRISIS}

\section{B. ERDÔS, MÁRTA}

Background: In a psychological crisis the appropriateness and stability of core meanings which organize one's personal identity are questioned by the individual. The disintegration of previous constructs results in a new coherence. In order to explore reconstructive processes, theories as Weinreich's (2003) Identity Structure Analysis, Bateson's (1972) second order change, as well as the theory of rite of passages, representing ideas on second chance or rebirth are discussed. Major questions of autobiographic texts related to crisis states are interpreted in the theoretical frameworks of discursive psychology (Harré, 1998; 2004; Kézdi, 2003) and Hanninen's (2004) model of narrative circulation.

Purpose: The goal is to explore self-reflective texts and narrative episodes, representing and constituting indepth transformational processes, with special regard to the liminal phase of the transition when an urgent need for intervention is present.

Methods: Qualitative content analysis of a cry for help conversation

Results: Results reveal certain processes of the disintegration and reconstruction of personal narratives, and connections between lived (experiential), inner, and told narratives, the latter representing cultural conventions in addition to personal features. Linguistic markers of these processes are discussed.

Conclusion: In a psychological crisis autobiographic scripts, the organization of life events and core meanings are subjects to substantial transformations. Though individuals are aware of the continuity of their existence and their identity, they often consider such major transformations of crisis states as rebirth or second chance. Certain characteristics of the middle or liminal phase of the changes - such as linguistic markers of paradoxes, ambivalence, and loss of control, the representation of specific temporal perspectives, and conceptual metaphors as condensed devices for organizing the scripts - as, for example, falling and holding on - serve as major anchoring points for the practitioner, carrying out the interventions.

Keywords: psychological crisis, liminality, second order change, meaning 